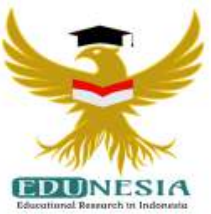

\title{
Meningkatkan Kreativitas Menggambar Menggunakan Media Finger Painting Pada Anak Kelompok B Paud Gentaralia Desa Jambat Akar Kecamatan Semidang Alas Maras Kabupaten Seluma
}

\author{
Mimpira Haryono1; Yuni Harlina² \\ ${ }^{1}$ PGPAUD, Universitas Dehasen Bengkulu, Indonesia \\ 2BAN PAUD Provinsi Bengkulu, Indonesia \\ ${ }^{1}$ Corresponding Email: mimpirampd1984@gmail.com, Phone Number : 0815 xxxx xxxx
}

Article History:

Received: Juli 14, 2020

Revised: Juli 20, 2020

Accepted: Juli 21, 2020

Published: Nov 01, 2020

Keywords:

child creativity,

Media Finger Painting.

Kata Kunci:

Kreativitas Anak,

Media Finger Painting.

How to cite:

Haryono, M., \& Harlina, Y. (2020). Meningkatkan Kreativitas Menggambar Menggunakan Media Finger Painting Pada Anak Kelompok B Paud Gentaralia Desa Jambat Akar Kecamatan Semidang Alas Maras Kabupaten Seluma. Edunesia : Jurnal Ilmiah Pendidikan, 1 (3): 21-30

This is an open access article under the $C C-B Y-N C-N D$

license

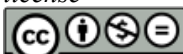

Abstract: The purpose of this research is to know the Children's drawing creativity by use Finger painting media in group B Paud Gentaralia village Jambat akar Kec. Semidang Alas Maras. Seluma, to know the increase in children's drawing creativity of finger painting media in Paud Gentaralia village Jambat akar kec. Semidang Alas Maras. Seluma. Class action Research ocused on the classroom situation, or commonly known as the Classroom Action research procedure used in cycle-shaped cycles. The main subject in this study is the children Paud Gentaralia Desa jambar akar Kec. Semidang Alas Maras. Group B Seluma numbered 15 persons. Data collection techniques using observation methods and documentation. Data analysis is done in a qualitatively qualitative quantitatively with its use to determine the improvement of processes expressed in a predicate, whereas quantitative data analysis is used to determine the increase in results by using a percentage.

Abstrak: Tujuan penelitian ini adalah untuk mengetahui kreativitas menggambar anak dengan menggunakan media finger painting kelompok B di Paud Gentaralia Desa Jambat Akar Kec. Semidang Alas Maras Kab. Seluma, untuk mengetahui peningkatan kreativitas menggambar anak kelompok B dengan penggunaan media finger painting di Paud Gentaralia Desa Jambat Akar Kec. Semidang Alas Maras Kab. Seluma. Penelitian Tindakan Kelas (PTK) yang difokuskan pada situasi kelas, atau lazim dikenal dengan classroom action research prosedur yang digunakan berbentuk siklus (cycle). Subjek utama dalam penelitian ini adalah anak Paud Gentaralia Desa Jambat Akar Kec. Semidang Alas Maras Kab. Seluma kelompok B berjumlah 15 Orang. Teknik pengumpulan data menggunakan metode observasi dan dokumentasi. Analisis data dilakukan secara deskriptif kualitatif-kuantitatif dengan penekananya digunakan untuk menentukan peningkatan proses yang dinyatakan dalam sebuah predikat, sedangkan analisis data kuantitatif digunakan untuk menentukan peningkatan hasil dengan menggunakan persentase. 


\section{A. Pendahuluan}

Anak Usia Dini merupakan sosok individu yang unik dan memiliki karakteristik yang khusus di bidang aspek perkembangannya. Pada usia 5-6 tahun merupakan periode terpenting untuk merangsang pertumbuhan otak anak dan di usia ini pula anak mengalami masa-masa peka dimana anak sangat sensitif sekali dalam menerima berbagai hal yang dapat mengembangkan seluruh potensi yang ada pada diri mereka.

Menurut Permendikbud No. 137 Tahun 2014 Tentang Standar Nasional Pendidikan Anak Usia Dini (PAUD) yang berisi standar tingkat pencapaian perkembangan anak usia 5-6 tahun. Pada usia ini merupakan masa peka bagi anak karena anak mulai sensitif untuk menerima rangsangan yang tepat. masa ini juga merupakan masa meletakkan dasar pertama setelah keluarga dalam mengembangkan berbagai macam perkembangan diantaranya nilai agama dan moral, fisik motorik, kognitif, bahasa, sosial emosional, dan seni.

Kreativitas salah satu potensi yang dimiliki oleh anak dan perlu dikembangkan sejak usia dini, setiap anak memiliki bakat kreatif yang berbeda dan ditinjau dari segi pendidikan, bakat kreatif perlu dikembangkan karena itu perlu dipupuk sejak dini, dan apabila bakat kreatif itu tersebut tidak dikembangkan maka tidak akan berkembang sesuai dengan harapan, bahkan bisa akan menjadi bakat terpendam yang tidak dapat terwujudkan.

Menurut Rachmawati (2010: 13) kreativitas adalah kemampuan seseorang untuk memikirkan sesuatu yang baru, baik berupa gagasan maupun karya nyata yang relatif berbeda dengan apa yang telah ada. Sedangkan menurut Munandar (2014: 25) kreativitas adalah kemampuan umum untuk menciptakan sesuatu yang baru, sebagai kemampuan untuk memberikan gagasan-gagasan baru yang dapat diterapkan dalam memecahkan masalah, atau berbagai kemampuan untuk melihat hubungan-hubungan baru antara unsur-unsur yang sudah ada sebelumnya. Sedangkan Menurut Munandar (2009: 12) kreativitas adalah kemampuan untuk membuat kombinasi baru, berdasarkan data, informasi, atau unsur-unsur yang sudah ada atau sudah ada dikenal sebelumnya, yaitu semua pengalaman dan pengetahuan yang telah diperoleh oleh seseorang selama hidup baik itu di lingkungan sekolah, keluarga maupun lingkungan masyarakat.

Ada beberapa cara yang dapat dilakukan untuk mengembangkan kreativitas anak melalui aktivitas seni baik berupa menggambar, melukis, mewarnai, membentuk sesuatu, musik, permainan, dan gerakan. Seluruh aktivitas ini mampu menjadikan anak untuk berpikir kreatif. Kegiatan menggambar anak merupakan salah satu kegiatan dimana anak dapat menciptakan sebuah karya. Kemampuan berolah seni rupa yang diwujudkan dengan keterampilan menuangkan ide, pengalaman, pengamatan ke dalam goresan garis, bentuk, warna sesuai dengan alat yang digunakan. Melalui menggambar anak diberi kebebasan untuk meluangkan ide, cita-cita, imajinasinya dengan gambaran dan coretan, dan biasanya setelah menggambar anak meminta gambarnya untuk diwarnai. Menggambar menjadi pintu masuk bagi stimulasi pembelajaran untuk menggembangkan kreativitas anak, menggambar merupakan salah satu aktivitas seni yang sangat disukai oleh anak-anak. Melalui kegiatan menggambar ini anak bebas berekspresi dan menuangkan ide-ide imajinasi mereka kedalam bentuk gambar. Dengan menggambar anak dapat menggunakan berbagai alat atau bahan untuk menciptakan sesuatu sesuai imajinasinya dan akan terlihat bagaimana kreasi maupun kreativitas anak (Al-Khalili, 2005: 50). 
Anak kreatif memerlukan perhatian khusus dari pendidik untuk mengembangkan dirinya, perhatian khusus ini bukan berarti mereka mendapatkan perlakuan istimewa, melainkan harus mendapatkan bimbingan sesuai dengan potensi kreatif agar tidak sia-sia, kreativitaslah yang memungkinkan anak meningkatkan perkembangannya, untuk pencapaian hal itu perlu sikap dan perilaku kreatif dipupuk sejak dini.

Rachmawati (2010: 15) mengatakan ada beberapa ciri perilaku anak yang berkreativitas adalah jika anak dapat tertarik pada kegiatan kreatif, mempunyai rasa ingin tahu yang besar, percaya diri dan mandiri, tekun dan tidak mudah bosan.

Sehubungan dengan pengamatan yang dilakukan peneliti di Paud Gentaralia Desa Jambat Akar Kec. Semidang Alas Maras Kab. Seluma terlihat masih ada beberapa anak belum mampu menggambar, dari 15 anak kelompok B dan 11 anak kurang paham dan kurang merespon apabila diajak menggambar oleh gurunya. Pada saat kegiatan menggambar berlangsung terdapat beberapa anak belum mampu menuangkan ide-ide mereka pada kertas yang akan digunakan untuk menggambar, anak mudah bosan ketika dia tidak mampu mengekspresikan ide-ide yang harusnya dituangkan pada kertas yang akan digunakan untuk menggambar, kemudian kegiatan pembelajaran yang digunakan oleh guru dalam mengembangkan kreativitas anak kurang bervariasi, kegiatan yang sering dilakukan guru adalah kegiatan akademik (calistung) sehingga banyak anak gampang bosan, tidak percaya diri dan kurang bebas berkreasi hal ini akan membuat anak kurang berani menonjolkan apa yang ada dalam dirinya. Selain itu penggunaan media pembelajaran yang guru gunakan masih belum tepat selama ini guru hanya menggunakan media menggambar menggunakan majalah dan menulis pada papan tulis kemudian anakanak menirukan gambar yang ditulis oleh guru tersebut. Belum lagi ditambah sarana prasarana yang masih minim.

Pada dasarnya banyak cara yang dapat dilakukan oleh guru PAUD untuk meningkatkan kreativitas anak dalam menggambar, salah satunya adalah dengan cara melakukan kegiatan menggambar dengan menggunakan media finger painting, karena menggambar merupakan kegiatan yang dapat mengembangkan ide, pikiran dan perasaan dalam kegiatan menggambar, menceritakan hasil gambar sesuai dengan imajinasi anak. Finger painting merupakan kegiatan melukis yang dilakukkan dengan menggunakan jarijari tangan.

Menurut Pakerti (2009: 36) Finger painting adalah jenis kegiatan membuat gambar yang dilakukan dengan cara menggoreskan adonan warna (bubur warna) secara langsung dengan jari tangan secara bebas pada kertas, cara melakukan media ini yakni menggunakan semua jari tangan anak, dari telapak tangan hingga pergelangan tangan anak. Finger painting didefinisikan pula sebagai teknik melukis secara langsung tanpa menggunakan bantuan alat seperti kuas ataupun pensil. Gerakan yang dilakukan dalam melakukan kegiatan Finger painting dapat melatih kreativitas anak di sekolah.

\section{B. Metode}

Metode yang digunakan dalam penelitian ini adalah Metode Penelitian Kualitatif dan Kuantitatif. Penelitian kualitatif adalah metode penelitian yang berfokus pada pemahaman terhadap fenomena sosial yang terjadi di masyarakat. Pada metode penelitian ini, peneliti menggunakan perspektif dari partisipan sebagai gambaran yang diutamakan dalam memperoleh hasil penelitian. Sedangkan metode Penelitian kuantitatif adalah metode penelitian yang bersifat sistematis dan menggunakan model-model yang bersifat 
matematis. Teori-teori yang digunakan serta hipotesa yang diajukan juga biasanya berkaitan dengan fenomena alam.

Jenis penelitian yang digunakan adalah Penelitian Tindakan Kelas (PTK) yang difokuskan pada situasi kelas, atau lazim dikenal dengan classroom action research prosedur yang digunakan berbentuk siklus (cycle). Wardhani (2006: 13) mengatakan bahwa penelitian tindakan kelas adalah penelitian yang dilakukan oleh guru di dalam kelasnya sendiri melalui refleksi diri, dengan tujuan untuk memperbaiki kinerjanya sebagai guru, sehingga hasil belajar siswa menjadi meningkat. Dalam PTK ini peneliti menggunakan model Jhon elliot maka dalam setiap siklus terdiri dari empat kegiatan pokok yaitu: perencanaan (planning), pelaksanaan (acting), pengamatan (observing), dan refleksi (reflection).

Penelitian ini dilakukan pada Paud Gentaralia Desa Jambat Akar Kecamatan Semidang Alas Maras Kabupaten Seluma. Pelaksanaan penelitian ini dilakukan selama tiga bulan mulai bulan Februari sampai dengan April 2020.

Kehadiran peneliti sangat diperlukan dalam setiap kegiatan di tempat penelitian karena peneliti berperan sebagai perencana, pelaksana tindakan, pengamat, reflektor dan sebagai pelapor hasil penelitian. Sebagai subyek pemberi tindakan, peneliti bertindak sebagai pengajar atau guru model yang bertugas yang membuat rancangan pelaksanaan pembelajaran Harian (RPPH) sekaligus menyampaikan bahan ajar selama proses pembelajaran. Di samping itu, peneliti juga mengumpulkan dan menganalisis data serta sebagai pelapor hasil penelitian

Menurut Arikunto (2011: 109) subjek penelitian merupakan sesuatu yang kedudukannya sentral karena pada subjek penelitian data tentang variabel yang diteliti dan diamati oleh peneliti. Subjek peneliti ini diperlukan untuk memperoleh keterangan mengenai data dan informasi apa saja yang menjadi sasaran penelitian dalam bentuk perkataan maupun perbuatan yang sedang diamati. Subjek penelitian ini adalah anak pada kelompok B (Usia 5-6 Tahun) yang berjumlah 15 orang di Paud Gentaralia Desa Jambat Akar Kecamatan Semidang Alas Maras Kabupaten Seluma Lebih rinci lihat tabel berikut:

Tabel 1.

Subjek Penelitian

\begin{tabular}{cccc}
\hline \multirow{2}{*}{ Kelompok Usia } & \multicolumn{2}{c}{ Ket } & \multirow{2}{*}{ Total } \\
\cline { 2 - 3 } & Lk & Pr & \\
\hline 5-6 Tahun & 7 & 8 & 15 \\
\hline
\end{tabular}

Sumber: Dokumentasi PAUD GENTARALIA TP. 2020.

Indikator keberhasilan pada penelitian ini adalah terjadi peningkatan kreativitas menggambar anak dengan menggunakan media finger painting kelompok B di Paud Gentaralia Desa Jambat Akar Kecamatan Semidang Alas Maras Kabupaten Seluma. Indikator penelitian ini dikatakan berhasil jika: 1) Anak tertarik pada kegiatan kreatif. 2) Anak mempunyai rasa ingin tahu yang besar. 3) Anak percaya diri dan mandiri. 4) Anak tekun dan tidak mudah bosan.

Instrumen pengumpulan data adalah alat bantu yang dipilih dan digunakan oleh peneliti dalam kegiatannya mengumpulkan data agar kegiatan tersebut menjadi sistematis dan dipermudah olehnya (Arikunto, 2005: 101). Dalam penelitian ini menggunakan instrumen pengumpulan data berupa pedoman lembar observasi dan dokumentasi. 
Instrumen untuk penelitian ini terdiri dari indikator- indikator yang berkaitan dengan aspek yang diamati.

Prosedur Penelitian Tindakan Kelas ini terdiri dari dua siklus tindakan dalam pembelajaran yaitu siklus I dan II, masing-masing siklus terdiri dari 2 kali pertemuan. Dalam setiap siklusnya terdiri dari empat elemen penting yaitu perencanaan, pelaksanaan, observasi/pengamatan, refleksi.

Data yang digunakan dalam penelitian tindakan kelas ini ada 2 yaitu: a) Data Kualitatif yaitu data yang diperoleh dari hasil observasi terhadap aktivitas belajar anak dan kinerja guru selam proses belajar mengajar berlangsung dibantu oleh rekan sejawat dengan mengisi lembar observasi. b) Data kuantitatif yaitu data yang diperoleh dari hasil tes setiap akhir siklus berupa lembar kerja anak yang dianalisis.

Adapun Sumber Data terdiri dari: a) Data primer Menurut Hasan (2002: 82) data primer ialah data yang diperoleh atau dikumpulkan langsung dilapangan oleh orang yang melakukan penelitian atau yang bersangkutan yang memerlukannya, data primer didapat dari sumber informan yaitu individu atau perorangan seperti hasil wawancara yang dilakukan oleh peneliti data primer ini antara lain: catatan hasil wawancara, hasil observasi lapangan, data-data mengenai informan. B) Data sekunder Data sekunder adalah data yang diperoleh atau dikumpulkan oleh orang yang melakukan penelitian dari sumber-sumber yang telah ada (Hasan, 2002: 58). Data ini digunakan untuk mendukung informasi primer yang telah diperoleh yaitu dari kardus pustaka, literatur, penelitian terdahulu, buku, dan lain sebagainya.

Teknik pengumpulan data yang digunakan dalam penelitian ini adalah observasi dan dokumentasi. Teknik analisis data yang digunakan dalam penelitian ini adalah analisis data deskriptif kualitatif-kuantitatif. Menurut Sanjaya (2009: 106), analisis data adalah proses mengolah dan mengintepretasikan data dengan tujuan mendudukan berbagai informasi sesuai dengan fungsinya sehingga memiliki makna dan arti yang jelas. Analisis data kualitatif digunakan untuk menentukan peningkatan proses yang dinyatakan dalam sebuah predikat, sedangkan analisis data kuantitatif digunakan untuk menentukan peningkatan hasil dengan menggunakan persentase. Analisis kualitatif dalam penelitian ini dinyatakan dalam sebuah predikat yang menunjuk pada pernyataan keadaan dan ukuran kualitas sehingga hasil penilaian berupa bilangan kemudian diubah menjadi sebuah predikat. Dalam penelitian ini, peneliti menggunakan predikat BB (Belum Berkembang), MB (Mulai Berkembang), BSH (Berkembang Sesuai Harapan), BSB (Berkembang Sangat Baik) yang kemudian dideskripsikan. Analisis dilakukan pada setiap siklus menggunakan rumus yang dari Purwanto (2010: 102) yaitu sebagai berikut:

$$
\mathrm{NP}=\frac{\mathrm{R}}{\mathrm{SM}} \times 100 \%
$$

Keterangan:

$\mathrm{NP} \quad=$ Nilai persen yang dicari/diharapkan

$\mathrm{R} \quad=$ Skor mentah yang diperoleh

$\mathrm{SM} \quad=$ Skor maksimum ideal dari nilai yang ada

$100=$ Bilangan tetap

Dari hasil perhitungan yang telah diperoleh selanjutnya dianalisis dan di sesuaikan ke dalam 4 kriteria dengan berpedoman sebagai berikut: 
Tabel 2

Pedoman kriteria

\begin{tabular}{ll}
\hline \multicolumn{1}{c}{ Kriteria } & Rentang Nilai \\
\hline 1 Belum Berkembang (BB) & $0 \%-25 \%$ \\
2 Mulai Berkembang (MB) & $26 \%-50 \%$ \\
3 Berkembang Sesuai Harapan (BSH) & $51 \%-75 \%$ \\
4 Berkembang Sangat Baik (BSB) & $76 \%-100 \%$ \\
\hline
\end{tabular}

Sumber: Yoni (2010: 175-176).

Kriteria keberhasilan penelitian berdasarkan dengan karakteristik penelitian tindakan kelas, dalam penelitian ini dinyatakan berhasil apabila terdapat perubahan atau peningkatan terhadap hasil belajar yang diperoleh oleh anak setelah diberikan tindakan. Penelitian ini dikatakan berhasil apabila pemahaman anak menunjukkan kriteria sangat BSB dengan rentang nilai mencapai $76 \%-100 \%$.

\section{Hasil dan Pembahasan}

1. Hasil

Berikut ini merupakan data hasil observasi meningkatkan kreativitas menggambar mengguanakan media finger painting pada kelompok B Paud Gentaralia Desa Jambat Akar Kecamatan Semidang Alas Maras Kabupaten Seluma dapat disajikan sebagai berikut:

\section{Tindakan Siklus ke I Pertemuam I}

Pada Siklus ke 1 peneliti laksanakan tindakan pada hari Senin, 20 April 2020. Adapun tahap-tahap tindakannya mulai dari tahap perencanaan, tahap pelaksanaan, tahap observasi/pengamatan, tahap analisis refleksi. Hasil analisis pada siklus 1 pertemuan 1 dari 15 anak kelompok B di Paud Gentaralia Desa Jambat Akar Kecamatan Semidang Alas Maras Kabupaten Seluma dari aspek yang diamati yang mendapatakan kriteria penilaian Berkembang Sesuai Harapan (BSH) 12 orang, dan Berkembang Sangat Baik (BSB) 3 orang. Sementara rata-rata skor secara keseluruhan aspek yang diamati sebesar 71\% (Berkembang Sesuai Harapan). Berdasarkan data yang diperoleh pada siklus I, peneliti membandingkan data hasil dengan kriteria penlaian yang telah ditetapkan oleh peneliti, ternyata belum optimal mencapai indikator keberhasilan yang telah ditetapkan sebelumnya yaitu 76\%-100\% (Berkembang Sangat Baik).

Berdasarkan data tersebut, dapat disimpulkan bahwa meningkatkan kreativitas menggambar anak dengan menggunakan media finger painting kelompok B di Paud Gentaralia Desa Jambat Akar Kecamatan Semidang Alas Maras Kabupaten Seluma melalui kegiatan rata-rata persentase yang diperoleh anak sebesar $\mathbf{7 1 \%}$ yang masih berada pada kriteria Berkembang Sesuai Harapan (BSH) dan belum mencapai indikator keberhasilan yang telah ditetapkan oleh peneliti sehingga perlu adanya evaluasi pada pelaksanaan siklus 1 agar ketika pelaksanaan siklus selanjutnya dapat berkembang maksimal menjadi Berkembang Sangat Baik (BSB) dan mencapai indikator keberhasilan yang telah ditetapkan yaitu $76 \%-100 \%$. 


\section{Tindakan Siklus ke II Pertemuan II}

Pada siklus ke II ini peneliti laksanakan pada hari Senin, 27 April 2020. Adapun tahap-tahap tindakannya sama halnya seperti pada tindakan siklus pertama yaitu: Tahap perencanaan, Tahap Pelaksanaan, Tahap observasi/pengamatan, Tahap analisis refleksi. Hasil analisis dari 15 anak kelompok B di Paud Gentaralia Desa Jambat Akar Kecamatan Semidang Alas Maras Kabupaten Seluma, dari aspek yang diamati yang mendapatkan kriteria Berkembang Sangat Baik (BSB) sebanyak 15 orang. Sementara rata-rata skor secara keseluruhan aspek yang diamati sebesar 97\% (Berkembang Sangat Baik). Berdasarkan data yang diperoleh pada siklus II, peneliti membandingkan data hasil dengan kriteria penilaian yang telah ditetapkan oleh peneliti, ternyata optimal mencapai indikator keberhasilan yang telah ditetapkan sebelumnya yaitu 76\%-100\% (Berkembang Sangat Baik).

Berdasarkan persentase di atas dapat disimpulkan bahwa kreativitas menggambar anak dengan mengguanakan media finger painting kelompok B di Paud Gentaralia Desa Jambat Akar Kecamatan Semidang Alas Maras Kabupaten Seluma yang dilaksanakan pada siklus II sudah mencapai indikator keberhasilan. Pada siklus II jumlah anak yang mencapai kriteria $76 \%-100 \%$.

Untuk melihat peningkatan kreativitas menggambar anak dengan menggunakan media finger painting kelompok B di Paud Gentaralia Desa Jambat Akar Kecamatan Semidang Alas Maras Kabupaten Seluma, dapat dilihat pada tabel berikut:

Tabel 3.

Peningkatan Kreativitas Menggambar Anak

\begin{tabular}{ccccc}
\hline Siklus ke- & $\begin{array}{c}\text { Total Skor } \\
\text { Aspek yang } \\
\text { diamati }\end{array}$ & $\begin{array}{c}\text { Total Skor } \\
\text { Maksimal }\end{array}$ & $\begin{array}{c}\text { Persentase } \\
\mathbf{( \% )}\end{array}$ & Kriteria \\
\hline 1 & 96 & 135 & $\mathbf{7 1 \%}$ & BSH \\
\hline II & 132 & 135 & $\mathbf{9 7 \%}$ & BSB \\
\hline
\end{tabular}

Peningkatan dari data yang diperoleh sesudah dilakukan tindakan pada siklus I dan siklus II. Persentase peningkatan kreativitas menggambar anak dengan mengguanakan media finger painting kelompok B di Paud Gentaralia Desa Jambat Akar Kecamatan Semidang Alas Maras Kabupaten Seluma mengalami peningkatan pada pelaksanaan tindakan siklus I sebesar 71\% kategori Berkembang Sesuai Harapan (BSH) dan mengalami peningkatan signifikan terjadi pada pelaksanaan tindakan siklus II menjadi 97\% kategori Berkembang Sangat Baik (BSB).

\section{Pembahasan}

Penelitian tindakan yang dilakukan untuk meningkatkan kreativitas menggambar anak dengan mengguanakan media finger painting kelompok B di Paud Gentaralia Desa Jambat Akar Kecamatan Semidang Alas Maras Kabupaten Seluma selama 2 siklus menunjukkan adanya peningkatan serta keberhasilan terhadap kreativitas anak. Adapun hasil pembahasannya adalah sebagai berikut:

Pada Siklus Ke I, dapat diketahui kreativitas menggambar anak meningkat secara bertahap. Peningkatan yang dicapai pada Siklus I belum mencapai indikator keberhasilan yang telah ditetapkan. Kemampuan anak dalam kreativitas menggambar dengan mengguanakan media finger painting Kelompok B di Paud Gentaralia Desa Jambat Akar 
Kecamatan Semidang Alas Maras Kabupaten Seluma mencapai 71\% dengan kriteria Berkembang Sesuai Harapan (BSH). Hasil persentase pencapaian yang diperolah pada Siklus I belum dapat mencapai persentase sebesar 76\% - 100\% dengan kriteria Berkembang Sangat Baik (BSB) sehingga penelitian dilanjutkan pada Siklus ke II. Hal ini dikarenakan anak belum memiliki ketertarikan atau kesiapan untuk menggambar sehingga tidak memperhatikan guru dan sering melamun sendiri walaupun anak ini sudah cukup umur. Anak lebih sering mengganggu teman dan keluar kelas sehingga tidak memperhatikan guru dan masih sulit untuk berkonsentrasi.

Anak kreatif memerlukan perhatian khusus dari pendidik untuk mengembangkan dirinya, perhatian khusus ini bukan berarti mereka mendapatkan perlakuan istimewa melainkan harus mendapatkan bimbingan sesuai dengan potensi kreatif agar tidak sia-sia, kreativitaslah yang memungkinkan anak meningkatkan perkembangannya, untuk pencapaian hal itu perlu sikap dan perilaku kreatif dipupuk sejak dini (Al-Khalili, 2005: $50)$.

Pada Siklus ke II, dapat diketahui kemampuan kreativitas menggambar anak meningkat secara bertahap. Peningkatan yang dicapai pada Siklus II mampu mencapai indikator keberhasilan yang telah ditetapkan. Hasil persentase pencapaian yang diperoleh pada Siklus II berhasil mencapai kriteria Berkembang Sangat Baik (BSB) dengan peningkatan mencapai $89 \%$. Berdasarkan peningkatan pencapaian kemampuan anak dalam kreativitas menggambar dengan mengguanakan media finger painting Kelompok B di Paud Gentaralia Desa Jambat Akar Kecamatan Semidang Alas Maras Kabupaten Seluma, anak-anak berhasil mencapai kriteria baik sampai $89 \%$ pada Siklus II. Kondisi anak-anak saat belajar menggambar dengan mengguanakan media finger painting di Kelompok B terlihat senang saat bermain. Situasi tersebut sangat mendukung dalam proses belajar anak-anak, sehingga anak-anak dapat dengan mudah menggambar dengan mengguanakan media finger painting dan mampu mencapai kriteria baik.

Hasil ini sejalan dengan pendapat Hamalik dan Sadiman (dalam Dhieni, 2008: 10) mengatakan bahwa dengan menggunakan media dapat mengatasi sikap pasif anak sehingga anak tidak hanya mendengarkan guru tetapi juga mengamati dan melakukan serta media mampu memberikan variasi dalam pembelajaran. Media yang digunakan seharusnya sesuai dengan kebutuhan anak.

Tabel 4.

Persentase Peningkatan kreativitas menggambar anak dengan mengguanakan media finger painting Sesudah Pelaksanaan Tindakan Siklus I, dan Tindakan Siklus II.

\begin{tabular}{llll}
\hline No & \multicolumn{1}{c}{ Indikator } & $\begin{array}{c}\text { Paersentase } \\
\text { Siklus I }\end{array}$ & $\begin{array}{c}\text { Persentase } \\
\text { Siklus II }\end{array}$ \\
\cline { 1 - 2 } 1 & Anak dapat tertarik pada kegiatan kreatif & & \\
\cline { 1 - 2 } 2 & Anak Mempunyai rasa ingin tahu & & \\
\cline { 1 - 2 } 3 & Anak percaya diri dan mandiri & & \\
\cline { 1 - 2 } 4 & Anak Tekun dan tidak mudah & & \\
\hline
\end{tabular}

Berdasarkan tabel di atas dapat diketahui adanya peningkatan dari data yang diperoleh sesudah dilakukan tindakan pada siklus I dan siklus II. Persentase Peningkatan kreativitas menggambar anak dengan mengguanakan media finger painting kelompok B di Paud Gentaralia Desa Jambat Akar Kecamatan Semidang Alas Maras Kabupaten Seluma, 
mengalami peningkatan, pada pelaksanaan tindakan siklus I 71\% Berkembang Sesuai Harapan (BHS) dan peningkatan signifikan terjadi pada pelaksanaan tindakan siklus II menjadi $97 \%$ artinya berkembang Sangat Baik (BSB)

Berdasarkan analisis yang dilakukan oleh peneliti kemampuan seni anak dengan penggunaan media finger painting mengalami peningkatan setelah pelaksanaan kegiatan dilakukan menggunakan Media finger painting di Paud Gentaralia Desa Jambat Akar Kecamatan Semidang Alas Maras Kabupaten Seluma, sehingga menimbulkan antusiasme yang tinggi dari anak dan stimulasi yang diberikan kepada anak dapat dilakukan secara maksimal karena stimulasi yang diberikan menggunakan beberapa variasi.

Pelaksanaan kegiatan dilakukan menggunakan media finger painting di Paud Gentaralia Desa Jambat Akar Kecamatan Semidang Alas Maras Kabupaten Seluma sesudah pelaksanaan sangat tepat untuk mengembangkan kreativiatas menggambar anak menggunakan media finger painting karena melalui kegiatan ini anak dapat tertarik pada kegiatan kreatif, anak mempunyai rasa ingin tahu, anak percaya diri dan mandiri, anak tekun dan tidak mudah Indikator-indikator keberhasilan sudah tercapai dengan baik terbukti dengan perolehan persentase yang dilakukan melalui 2 siklus yaitu siklus I dan II. Oleh karena itu, menerapkan kegiatan untuk meningkatkan kreativitas menggambar anak dapat tertarik pada kegiatan kreatif, mempunyai rasa ingin tahu yang besar, percaya diri dan mandiri, tekun dan tidak mudah bosan pada kelompok B sangat tepat.

\section{Kesimpulan}

Berdasarkan hasil penelitian dan pembahasan, maka peneliti menarik kesimpulan bahwa melalui penggunaan media pinger painting dapat meningkatkan kreativitas menggambar anak di Paud Gentaralia Desa Jambat Akar Kecamatan Semidang Alas Maras Kabupaten Seluma. Peningkatan tersebut dapat dilihat dari adanya peningkatan persentase setelah pelaksanaan tindakan pada siklus I dan siklus II. Pelaksanaan tindakan pada siklus I, persentase yang ditunjukkan dari siklus I sebesar 71\% (BSH) dikarenakan media pembelajaran finger painting yang peneliti gunakan hanya 1 set media saja untuk 15 orang anak dalam kelompok besar sehingga pembelajaran kurang maksimal. Kemudian peningkatan persentase yang cukup signifikan ditunjukkan pada pelaksanaan siklus II menjadi 97\% (BSB).

Adapun saran yang dapat peneliti sampaikan diharapkan kepada kepala Paud Gentaralia Pelaksanaan Penelitian Tindakan Kelas (PTK) ini dapat menjadi alternatif pemecahan masalah yang terjadi di lembaga sekolah dan menjadi acuan untuk Lembaga sekolah agar menjadi lebih baik dan bagi guru dapat menjadi alternatif kegiatan pembelajaran untuk menstimulasi perkembangan kreativitas anak agar dapat berkembang maksimal dan menjadi referensi serta motivasi untuk memberikan kegiatan pembelajaran yang tidak membosankan untuk anak.

\section{Daftar Pustaka}

Al-Khalili, (2005) Mengembangkan Kreativitas Anak. Jakarta: Pustaka Al-Kautsar.

Arikunto, S. (2011) Prosedur Penelitian Suatu Pendekatan Praktik. Jakarta: Rineka Cipta.

Arikunto, S. (2005) Penelitian Tindakan Kelas. Yogyakarta: Aditya Medra. 
Dhieni, N. (2008) Metode Pengembangan Bahasa. Jakarta: Universitas Terbuka.

Hasan, M. I. (2002). Pokok-pokok materi metodologi penelitian dan aplikasinya.

Munandar, U. (2014) Pengembangan Kreatifitas Anak Berbakat. Jakarta: Rineka Cipta.

Munandar, U. (2009) Pengembangan Kreativitas Anak Berbakat. Jakarta: Rineka Cipta.

Pakerti, W. (2009) Metode Pengembangan Seni. Jakarta: Universitas Terbuka.

Permendikbud, (2014) Standar Nasional Pendidikan Anak Usia Dini. Jakarta: Permendikbud.

Purwanto, M. N. (2010). Prinsip-prinsip dan teknik evaluasi pengajaran. Remaja Rosdakarya.

Rachmawati, Y. (2010) Strategi Pengembangan Kreativitas Pada Anak. Jakarta: Kencana

Sanjaya, W. (2009) Penelitian Tindakan Kelas. Jakarta: Kencana Media Group.

Wardhani, (2006) Penelitian Tindakan Kelas. Jakarta: Universitas Terbuka.

Yoni, A. (2010). Menyusun penelitian tindakan kelas. Yogyakarta: Familia. 